\title{
Pyrolysis Characteristics of Undervalued Wood Varieties in the Portuguese Charcoal Sector
}

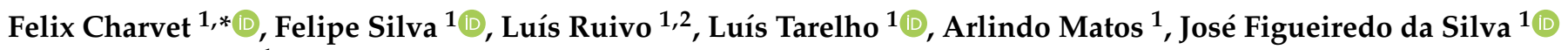 \\ and Daniel Neves ${ }^{1}$ \\ 1 Department of Environment and Planning, CESAM - Centre for Environmental and Marine Studies, \\ University of Aveiro, Campus Universitário de Santiago, 3810-193 Aveiro, Portugal; felipe.thalles@ua.pt (F.S.); \\ luis.ruivo@ua.pt (L.R.); ltarelho@ua.pt (L.T.); amatos@ua.pt (A.M.); jfs@ua.pt (J.F.d.S.); dneves@ua.pt (D.N.) \\ 2 Department of Materials and Ceramic Engineering, CICECO-Aveiro Institute of Materials, \\ University of Aveiro, Campus Universitário de Santiago, 3810-193 Aveiro, Portugal \\ * Correspondence: f.charvet@ua.pt; Tel.: +351-234-370-349
}

check for updates

Citation: Charvet, F.; Silva, F.; Ruivo, L.; Tarelho, L.; Matos, A.; Figueiredo da Silva, J.; Neves, D. Pyrolysis Characteristics of Undervalued Wood Varieties in the Portuguese Charcoal Sector. Energies 2021, 14, 2537. https://doi.org/10.3390/en14092537

Academic Editor: Biagio Morrone

Received: 2 March 2021

Accepted: 23 April 2021

Published: 28 April 2021

Publisher's Note: MDPI stays neutral with regard to jurisdictional claims in published maps and institutional affiliations.

Copyright: (c) 2021 by the authors. Licensee MDPI, Basel, Switzerland. This article is an open access article distributed under the terms and conditions of the Creative Commons Attribution (CC BY) license (https:// creativecommons.org/licenses/by/ $4.0 /)$.

\begin{abstract}
Charcoal production in Portugal is mostly based on the valorization of woody residues from cork oak and holm oak, the latter being considered a reference feedstock in the market. Nevertheless, since wildfire prevention became a priority in Portugal, after the recent dramatic wildfires, urgent actions are being conducted to reduce the fuel load in the forests, which is increasing the amount of biomass that is available for valorization. Additionally, biomass residues from agriculture, forest management, control of invasive species, partially burnt wood from post-fire recovery actions, and waste wood from storm devastated forests need also to be considered within the national biomass valorization policies. This has motivated the present work on whether the carbonization process can be used to valorize alternative woody biomasses not currently used on a large scale. For this purpose, slow pyrolysis experiments were carried out with ten types of wood, using a fixed bed reactor allowing the controlled heating of large fuel particles at 0.1 to $5{ }^{\circ} \mathrm{C} / \mathrm{min}$ and final temperatures within $300-450{ }^{\circ} \mathrm{C}$. Apart from an evaluation of the mass balance of the process, emphasis was given to the properties of the resulting charcoals considering its major market in Portugal—barbecue charcoal for both recreational and professional purposes.
\end{abstract}

Keywords: charcoal; biomass; woody residues; pyrolysis; carbonization

\section{Introduction}

The European Commission has adopted a circular and sustainable bioeconomy strategy requesting new insights in circular business models ideally based on local resources, as a means to drive the modernization of industries and tackle global climate and environmental challenges [1]. Following these purposes, Portugal has implemented some instruments that contribute to the strengthening of the national bioeconomy, namely the National Plan for the Promotion of Biorefineries [2] focusing on the valorization of lowvalue biomass feedstocks. In this regard, distinct processes can be considered to convert biomass into energy, biofuels, and bioproducts, some of which already with industrial application. Biomass slow pyrolysis is one of those processes that, due to its versatility and thermal/material synergies with other processes (e.g., combustion), is receiving increasing industrial interest in the context of new advanced biorefineries.

A common aspect of biomass pyrolysis processes is that they are thermally driven. Biomass particles - containing moisture, lignin, holocellulose, extractives, and ash-undergo sequential transformations as a function of temperature. These transformations start by drying as the temperature rises to $100{ }^{\circ} \mathrm{C}$, which is followed by subsequent cleavage reactions (e.g., dehydrations and depolymerizations) at higher temperatures, all of these concurring to the volatilization of a large array of compounds [3]. The final result is that the biomass converts into three main product fractions: bio-oil, permanent gases, and 
biochar (in this work referred as charcoal according to e.g., [4]), with the proportions and composition of these being dependent on the nature of biomass, namely the relative proportions of lignin and cellulose, and the operating conditions, such as temperature and heating rate. In the case of slow pyrolysis processes where the goal is to maximize the yield of charcoal, a combination between low temperatures $\left(<450^{\circ} \mathrm{C}\right)$, low heating rates $\left(<10^{\circ} \mathrm{C} / \mathrm{min}\right)$, and high lignin content fuels lead to better results [5-7]. Still, the process can be fine-tuned to adjust the properties of charcoal (e.g., heating value, carbon content, volatile matter, porosity) according to the needs of distinct applications (fuels, reducing agents, cosmetics, art products, soil ameliorants, purification materials [8-10]).

Among the products arising from biomass slow pyrolysis, only charcoal has met commercial applications worldwide, and its utilization dates back to ancient times [11,12]. It has been a major source of energy in Europe, namely for iron melting [13], sometimes replacing fossil fuels in some applications during the industrial revolution [14]. Charcoal production is still in practice in various European regions [15], although its real contribution to the valorization of biomass feedstocks is poorly understood. In Portugal, a recent study on the mapping of charcoal production in the district of Portalegre (Alentejo Region) revealed hundreds of kilns [16], almost all of them operating traditionally. Although similar situations are likely to be found in adjacent districts, pointing the fact that this is a relevant socio-economic activity, charcoal production is seldom addressed in studies dealing with the national bioenergy sector (e.g., $[17,18])$.

Given that charcoal production mainly relies on traditional methods and considering its distribution across rural areas, it becomes clear that this is perhaps the branch of the bioenergy sector where funding and scientific research can be more successful in pushing forward. Carbonization can be more rapidly leveraged based on existing know-how and infrastructure at lower investment costs. Moreover, it has the potential to sustain or increase the economic activity in regions of low population density, contributing to forest fire prevention in Southern European countries-especially after the dramatic death toll in the recent years [19] — since a low risk of fire is often associated to well-managed forests. In this regard, charcoal production can be viewed as a complementary solution in well-balanced biomass valorization systems where certain types of biomass, especially low value woode.g., residues from agroforestry activities, wood from invasive species control, partially burnt wood from post-fire recovery actions, or waste wood from storm devastated forestsare preferably valorized by carbonization instead of combustion or pellets production, which nearly represents the present situation [20,21]. Large pieces of waste wood, such as tree trunks and stumps, may be especially suited for charcoal production as they are compatible with current carbonization methods and technologies where fuel chipping is not required. However, to become a regular practice, laboratory research is needed to demonstrate the yield and quality of charcoal arising from the abovesaid types of wood, including its suitability for distinct markets, so that the industrial interest for the carbonization of alternative feedstock may increase. For instance, charcoal production in the district of Portalegre (Portugal) largely relies on waste wood from cork oak and holm oak [16], while there are vast areas of alternative feedstocks nearby (e.g., maritime pine and eucalyptus) frequently affected by large forest fires, which are not used for carbonization to the same extent. One reason for this is that charcoal production in the Portalegre district, as well as throughout the country, is mainly intended for barbecueing, both in household and professional appliances (e.g., restaurants), the latter being the preferred market for many producers. It turns out that professional consumers mainly request charcoal from holm oak and cork oak, as they have the perception that these charcoals offer greater value for the money ("it weighs more", "it burns longer", according to some consumers), which ends up conditioning the type of wood being processed by charcoal producers. However, the European standard EN1860-2-2005:E [22] establishes the minimum quality requisites for barbeque charcoal, thus offering the basis to evaluate the suitability of alternative types of wood for charcoal production. 
In this context, this work aims to provide insights into the properties and yield of charcoal produced from ten types of wood common in Southern Europe, under operational conditions relevant for biomass carbonization technologies. The holm oak is taken here as a reference wood according to the referred charcoal demand-supply context in Portugal. Furthermore, it extends the results and consolidates the analysis carried out in our previous work [23], contributing to diversifying the fuel supply chain and expanding the relevance of existing charcoal production activities within the Portuguese (and South-European) bioenergy sector.

\section{Materials and Methods}

\subsection{Biomass Feedstocks}

Wood samples from ten species of trees found in Southern Europe were tested in this work: eucalyptus globulus, cork oak, poplar, acacia mimosa, Australian blackwood, gray willow, holm oak, olive tree, maritime pine, and stone pine. The wood feedstocks were collected as logs of 7-12 cm in diameter and left to dry to equilibrium condition (about $10 \mathrm{wt} \%$ moisture) under cover for at least three months after the trees were cut. The logs were debarked and modeled in a parallel lathe into cylindrical particles of $\approx 50 \mathrm{~mm}$ in diameter and $\approx 55 \mathrm{~mm}$ in length (measured along the fiber direction). Wood fines generated during the cutting of the cylindrical particles were collected and further ground, if needed, for subsequent analyses, including proximate composition (ash, fixed carbon, and volatile matter, according to CEN/TS 15148:2005 and CEN/TS 14775:2004), elemental composition (CHNS) and lignin content (based on Tappi $222 \mathrm{om}-02$ ). The heating value was approximated from the respective elemental composition according to an empirical correlation [24], whereas the apparent volumetric mass (hereinafter referred as apparent density) was determined from the mass and geometrical dimensions of the dry wood particles. Table 1 shows the relevant wood properties measured in this work, including the uncertainties given as standard deviations based on three replicates whenever possible.

Table 1. Physicochemical properties of feedstocks.

\begin{tabular}{|c|c|c|c|c|c|c|c|}
\hline \multicolumn{8}{|c|}{ Average \pm One Std. Deviation, (Dry Basis) } \\
\hline Fuels & $\begin{array}{l}\text { Volatile } \\
\text { Matter }\end{array}$ & Ash & $\mathrm{O} / \mathrm{C}$ & $\mathrm{H} / \mathrm{C}$ & $\begin{array}{c}\text { Apparent } \\
\text { Density }\end{array}$ & LHV (2) & LIGNIN \\
\hline & (wt \%) & (wt \%) & $(\mathrm{kg} / \mathrm{kg})$ & $(\mathrm{kg} / \mathrm{kg})$ & $\left(\mathrm{kg} / \mathrm{m}^{3}\right)$ & (MJ/kg) & $(w t \%)$ \\
\hline Holm oak & $82.7 \pm 2.7$ & $0.96 \pm 0.04$ & $0.95 \pm 0.02$ & $0.14 \pm 0.004$ & $890 \pm 23$ & $17.1 \pm 1.3$ & $23.4 \pm 1.2$ \\
\hline Olive tree & $83.3 \pm 0.7$ & $0.40 \pm 0.06$ & $0.89 \pm 0.01$ & $0.14 \pm 0.005$ & $774 \pm 25$ & $18.2 \pm 1.1$ & $23.6 \pm 1.2$ \\
\hline Cork oak & $83.4 \pm 0.9$ & $0.80 \pm 0.03$ & $0.98 \pm 0.02$ & $0.14 \pm 0.005$ & $709 \pm 23$ & $16.7 \pm 1.3$ & $21.4 \pm 1.1$ \\
\hline Eucalyptus globulus & $86.1 \pm 0.8$ & $0.20 \pm 0.02$ & $1.01 \pm 0.01$ & $0.14 \pm 0.004$ & $624 \pm 35$ & $16.4 \pm 1.0$ & $19.4 \pm 1.0$ \\
\hline Acacia mimosa & $85.5 \pm 0.6$ & $0.46 \pm 0.05$ & $0.96 \pm 0.02$ & $0.15 \pm 0.004$ & $572 \pm 7$ & $17.4 \pm 1.2$ & $20.0 \pm 1.0$ \\
\hline Gray willow & $84.7 \pm 0.3$ & $0.39 \pm 0.03$ & $0.90 \pm 0.01$ & $0.14 \pm 0.004$ & $551^{(1)}$ & $18.0 \pm 0.8$ & $21.7 \pm 1.1$ \\
\hline Maritime pine & $82.0 \pm 1.3$ & $0.14 \pm 0.04$ & $0.88 \pm 0.01$ & $0.14 \pm 0.006$ & $521 \pm 28$ & $18.3 \pm 1.2$ & $28.3 \pm 1.4$ \\
\hline Australian blackwood & $84.4 \pm 0.4$ & $0.50 \pm 0.11$ & $0.90 \pm 0.01$ & $0.14 \pm 0.003$ & $474^{(1)}$ & $18.1 \pm 0.7$ & $19.9 \pm 1.0$ \\
\hline Stone pine & $82.3 \pm 0.4$ & $0.29 \pm 0.03$ & $0.83 \pm 0.01$ & $0.14 \pm 0.002$ & $474^{(1)}$ & $19.0 \pm 0.8$ & $29.5 \pm 1.5$ \\
\hline Poplar & $85.2 \pm 0.3$ & $0.34 \pm 0.17$ & $0.90 \pm 0.01$ & $0.14 \pm 0.002$ & $415^{(1)}$ & $17.9 \pm 0.8$ & $24.6 \pm 1.2$ \\
\hline
\end{tabular}

\subsection{Experimental Facility}

The experimental facility (Figure 1) comprises a fixed bed reactor and ancillary systems used to control the operating conditions (temperatures, pressures, gas flow rates) and collect samples of pyrolysis gases, pyrolysis liquids, and charcoal. This facility was adapted from an existing laboratory pyrolysis setup available at the University of Aveiro [25] by changing the reactor configuration and operation from fluidized bed to fixed bed. The reactor's main body consists of an AISI 310 refractory steel tube (70 mm internal diameter, $920 \mathrm{~mm}$ length) with three sets of flanges enabling gas inflows/outflows, and pressure and temperature measurements. The reactor was placed inside a $3 \mathrm{~kW}_{\mathrm{e}}$ vertical electric furnace. The wood 
sample is held at the middle height of the reactor by an all-welded refractory steel body placed inside the reactor main tube; this steel body comprises a concentric tube $(62 \mathrm{~mm}$ internal diameter) and the inlet pipe for carrier gas (in this work, $99.999 \% \mathrm{v} \mathrm{N}_{2}$ ). Insulating material (ceramic wool) was placed inside the upper and lower parts of the reactor tube to reduce axial temperature gradients across the reaction chamber. The reactor also includes a pre-heating zone for the incoming $\mathrm{N}_{2}$ carrier gas and a side port close to the lower set of flanges enabling to purge the reactor tube before the carbonization experiments (also with $\mathrm{N}_{2}$ ). The temperature inside the reactor was monitored $10 \mathrm{~mm}$ above the wood sample by a K-type thermocouple inserted through the reactor top flange (T1 in Figure 1). On the upper part of the reactor, the escaping pyrolysis volatiles go through the side flanged port into a high-temperature line at $400-450{ }^{\circ} \mathrm{C}$ and subsequent systems for collecting samples of bio-oil and pyrolysis gas (letters D to J in Figure 1). Despite the latter experimental features, the analysis of bio-oil and pyrolysis gas is beyond the scope of this work.

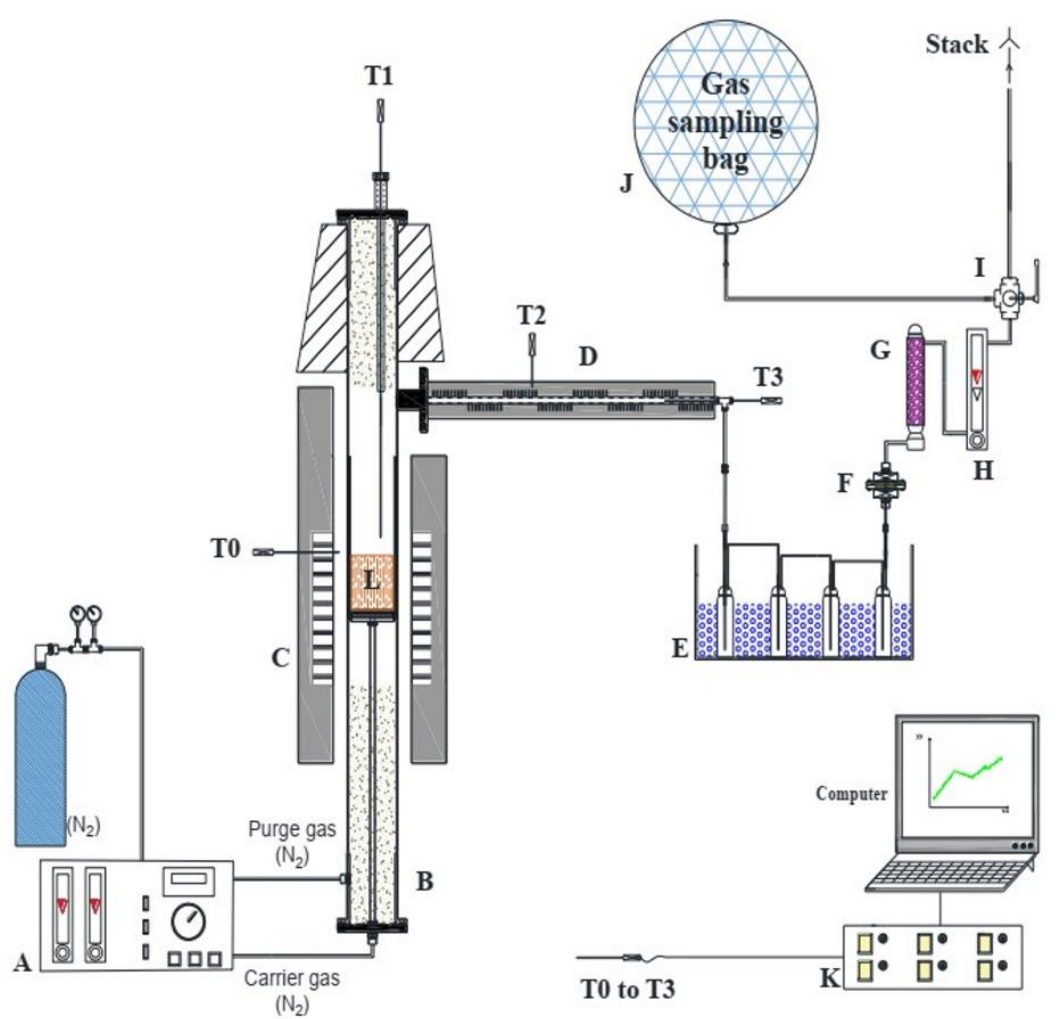

Figure 1. Layout of the fixed-bed pyrolysis facility. (A) Furnace temperature and carrier gas flow-rate control unit, (B) fixed bed reactor, (C) electrically heated reactor furnace, (D) electrically heated gas sampling line, (E) ice bath, (F) quartz filter, $(\mathbf{G})$ silica gel tower, $(\mathbf{H})$ gas flowmeter, $(\mathbf{I})$ three-way ball valve, (J) gas sampling bag, (K) data acquisition and control system, (L) cylindrical wood particle; T0 to T3-K-type thermocouples.

\subsection{Experimental Procedure}

Before each carbonization experiment, the cylindrical wood particles were dried at $105 \pm 5^{\circ} \mathrm{C}$ for $24 \mathrm{~h}$ and then cooled to room temperature in a desiccator containing silica gel. Prior to the experiments, the reactor was heated to $600{ }^{\circ} \mathrm{C}$ in air atmosphere to burn pyrolytic residues from previous experiments. The dry and cold wood particles were weighed (precision of $0.001 \mathrm{~g}$ ) and measured for both diameter and length (precision of $0.1 \mathrm{~mm}$ ), before being placed inside the reactor. The carbonization experiments were performed to a final temperature of $300,350,400$, or $450{ }^{\circ} \mathrm{C}$ (T1 in Figure 1), using heating rates of $0.1,1$, or $5^{\circ} \mathrm{C} / \mathrm{min}$, and a constant holding time of $60 \mathrm{~min}$. Although the experimental facility allowed heating rates above $5{ }^{\circ} \mathrm{C} / \mathrm{min}$, in practice, higher rates are difficult to 
achieve with fuel particles of the size used in this work $(\approx 50 \times 55 \mathrm{~mm}$ cylinders $)$ due to inherent heat transfer limitation; thus, it was decided to use maximum heating rates of $5{ }^{\circ} \mathrm{C} / \mathrm{min}$ to limit this effect. A continuous $\mathrm{N}_{2}$ flow rate of $\approx 0.25 \mathrm{l}_{\mathrm{n}} / \mathrm{min}\left(\mathrm{l}_{\mathrm{n}}\right.$ means a liter referred at $1.013 \times 10^{5} \mathrm{~Pa}$ and $273 \mathrm{~K}$ ) was used to ensure an inert atmosphere inside the reactor. Once the holding time was finished, the temperature control was switched off, and the reactor was allowed to cool to room temperature, maintaining the flow of $\mathrm{N}_{2}$. The charcoal particles resulting from the carbonization stage were recovered, weighed (precision of $0.001 \mathrm{~g}$ ), and its dimensions measured (precision of $0.1 \mathrm{~mm}$ ) before being stored in a desiccator for later characterization.

\subsection{Charcoal Characterization}

A fraction of each charcoal particle recovered from the fixed bed reactor was handground to obtain chemically homogeneous particles and subjected to analysis of proximate composition (ash, fixed carbon, and volatile matter, according to CEN/TS 15148:2005 and CEN/TS 14775:2004), and elemental composition (CHNS). For a limited number of samples, pore properties were analyzed via physical $\mathrm{N}_{2}$ adsorption at $77 \mathrm{~K}$, after proper degasification under vacuum at $80^{\circ} \mathrm{C}$ for $12 \mathrm{~h}$. The total pore volume and average pore size were estimated by the Barrett-Joyner-Halenda method. The remaining fraction of each charcoal particle was broken by hand into small particles of $\approx 1 \mathrm{~cm}^{3}$. These particles were dried at $105 \pm 5{ }^{\circ} \mathrm{C}$ for $24 \mathrm{~h}$, degassed, and impregnated with ethanol under vacuum, and its apparent density was measured according to the Archimedes' principle [26]. Moreover, the microstructure of the charcoal samples was assessed by scanning electron microscopy (SEM, Hitachi, TM4000 Plus) operated at $25.0 \mathrm{kV}$. The analysis was performed on a crosssection cut perpendicular to the direction of the wood fibers. Measurement uncertainties associated to charcoal properties are given as standard deviations based on three replicates.

\subsection{Overview of the Experiments}

Forty carbonization experiments were done in this work. Apart from a few experiments enabling calibrating ancillary systems and developing the test procedure, the experiments can be divided into 3 groups. The first group of experiments (Section 3.3) aimed to determine the effect of temperature on charcoal's fixed carbon content and yield. This is relevant because the scope of this work is charcoal production from distinct wood types, and therefore, it is necessary to define the temperature at which the tests will be done. To select the suitable level of temperature, the guideline given in EN1860-2-2005:E standard was followed, which establishes a minimum carbon content of $75 \mathrm{wt} \%$ (dry basis) for barbecue charcoal [22]. These experiments were done with holm oak and cork oak, i.e., the two widely used types of wood for charcoal production in Portugal, and also with eucalyptus, to check for plausible variations arising from a distinct type of wood. Four temperatures (within the range of 300 to $450{ }^{\circ} \mathrm{C}$ ) and a constant heating rate of $1^{\circ} \mathrm{C} / \mathrm{min}$ were used for this purpose. The second group of experiments (Section 3.4) aimed to evaluate how charcoal's yield and properties vary among the ten types of wood listed in Table 1, at $1{ }^{\circ} \mathrm{C} / \mathrm{min}$ and final temperature according to the results from the first group of experiments. The final group of experiments (Section 3.5) aimed to provide insight into the effect of varying the heating rate and wood moisture in the carbonization process. A number of experimental conditions were tested in duplicate in order to evaluate the uncertainties associated with the carbonization experiments.

\section{Results and Discussion}

\subsection{Evaluation of Measurement Uncertainties}

The experience with the experimental facility showed that successive pyrolysis tests can be done with good repeatability in terms of heating rate $\left( \pm 0.1^{\circ} \mathrm{C} / \mathrm{min}\right.$ of setpoint) and final temperature $\left( \pm 5^{\circ} \mathrm{C}\right.$ of setpoint $)$. Examples of temperature-time profiles can be found in [23]. The largest deviations between actual and setpoint temperatures always occur during the initial heating stage (below $150{ }^{\circ} \mathrm{C}$ ) due to the thermal inertia of the 
reactor and wood particles. Concerning the yields of charcoal, results show uncertainties of $\pm 2 \%$ of average values. For the physical-chemical analysis of wood and charcoal (proximate/elemental compositions, apparent density, and lignin content), results show deviations typically within \pm 2 to $\pm 5 \%$ of average values, depending on the parameter. The exception is the ash contents with uncertainties typically of $\pm 20 \%$, although higher values were also obtained (see e.g., Table 1); this is partially due to the low ash contents of some woods/charcoals, which adds uncertainty to the measurements. Regarding apparent density, variations of $\pm 5 \%$ of the average values were observed. A comparison between the geometrical method and the alternative method based on Archimedes' principle showed a reasonable agreement [23].

Despite the relatively low uncertainties arising from the analysis of individual samples, it should be noted that the properties of wood/charcoal can vary between logs or even within the same log. Although this subject is outside the scope of this work, an initial assessment of this variability was done by analyzing a limited number of wood samples for proximate composition and apparent density. The results suggested that the ash content and bulk density are the parameters with higher variability. For example, differences in densities up to $100 \mathrm{~kg} / \mathrm{m}^{3}$ were found between samples of holm oak wood from distinct logs. These differences can lead to the production of charcoals with different properties, and one should be aware of such heterogeneity associated with biomass feedstocks.

\subsection{Feedstock Properties}

Figure 2 plots the relevant properties of the wood feedstocks tested in this work, which are expressed as ratios relative to those of holm-oak wood. It can be seen that apart from the apparent density, the physicochemical properties of wood vary little between species, being typically within 0.8 and 1.2 of those observed for holm oak wood. Differences in apparent density are larger and highlight holm oak as the densest wood, with around $900 \mathrm{~kg} / \mathrm{m}^{3}$, and poplar as the least dense wood, with just above $400 \mathrm{~kg} / \mathrm{m}^{3}$. In this regard, three groups of wood can be drawn: group I with up to around $500 \mathrm{~kg} / \mathrm{m}^{3}$ includes maritime pine, Australian blackwood stone pine, and poplar; group II within around 500 and $700 \mathrm{~kg} / \mathrm{m}^{3}$ includes eucalyptus globulus, acacia mimosa, and gray willow; and group III with above $700 \mathrm{~kg} / \mathrm{m}^{3}$ includes holm oak, olive tree, and cork oak. The lignin content also varies somewhat between woods, with the two pine species showing the highest values (>28 wt \%), and eucalyptus and acacias showing the lowest $(<20 \mathrm{wt} \%)$. As expected, the lignin content shows a slight negative correlation with the respective O/C mass ratios of wood (Figure $2 \mathrm{~b}$ ); in the opposite direction goes the volatile matter content, which shows a positive correlation with the respective $\mathrm{O} / \mathrm{C}$ ratios. The ash content falls outside the 0.8-1.2 range when plotted as ratios relative to that of holm oak, although the values obtained for the whole number of woods tested show a small variation if expressed by dry fuel mass: between 0.20 and $0.96 \mathrm{wt} \%$ (see Table 1 ). Indeed, with the exceptions of holm oak and cork oak, the other wood types showed ash contents below $\approx 0.5 \mathrm{wt} \%$. 

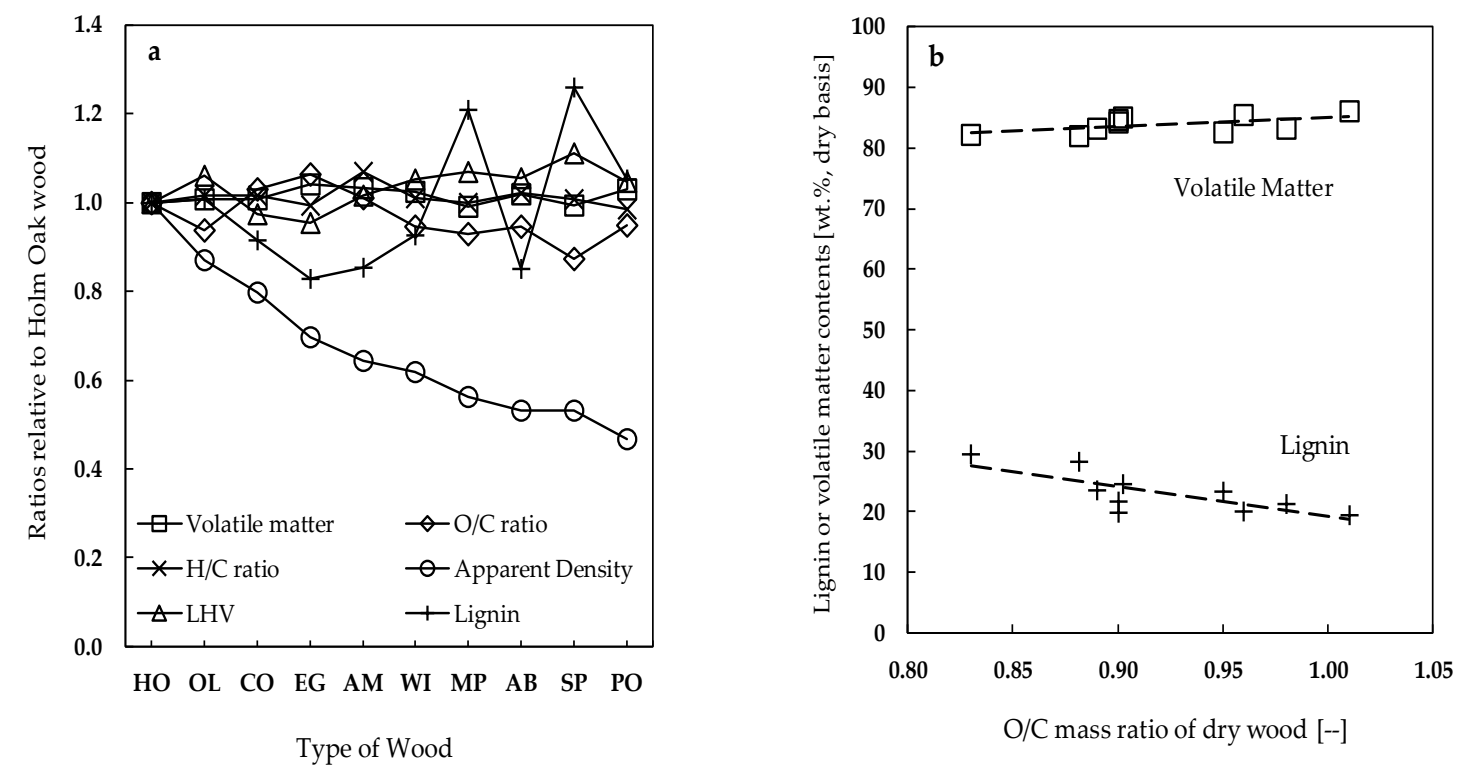

Figure 2. Ratios of selected physicochemical properties of distinct wood types in relation to those of holm oak wood (a), and lignin or volatile matter contents of wood as a function of the respective $\mathrm{O} / \mathrm{C}$ mass ratios (b). HO-holm oak, OL-olive tree, AM-acacia mimosa, EG—eucalyptus globulus, $\mathrm{CO}$ —cork oak, WI-gray willow, AB-Australian blackwood, SP—stone pine, $\mathrm{MP}$-maritime pine, $\mathrm{PO}$ - poplar.

\subsection{Effect of Final Carbonization Temperature}

Figure 3 shows the charcoal's fixed carbon content and yield as a function of final carbonization temperature, using a constant heating rate of $1{ }^{\circ} \mathrm{C} / \mathrm{min}$. The fact that similar trends were observed for holm oak, cork oak, and eucalyptus globulus, which exhibit quite different properties (Table 1), suggests that this behavior will be valid for the remainder wood types tested in this work. The temperature causes different effects on charcoal's fixed carbon content and yield. The fixed carbon content increases with temperature increase, while the respective yield decreases. The effect of temperature is more evident in the case of fixed carbon content. An increase in temperature from 300 to $450{ }^{\circ} \mathrm{C}$ leads to an increase in fixed carbon content from around $60 \mathrm{wt} \%$ to almost $80 \mathrm{wt} \%$, while the respective yields decrease from around $40 \mathrm{wt} \%$ to just below $35 \mathrm{wt} \%$.

These results show that a minimum final carbonization temperature of about $400{ }^{\circ} \mathrm{C}$ is required for the charcoal to reaches the threshold of $75 \mathrm{wt} \%$ (dry basis) of fixed carbon content, as established in the EN1860-2-2005:E standard for barbeque charcoal. Higher temperatures allow the production of charcoal with higher fixed carbon contents, albeit at the expense of lower mass yields. For this reason, and considering that some works dealing with practices of charcoal production report kiln temperatures typically around $400{ }^{\circ} \mathrm{C}[27,28]$, a final carbonization temperature of $400{ }^{\circ} \mathrm{C}$ was used during the tests aimed to evaluate the effect of wood type on the carbonization process. 


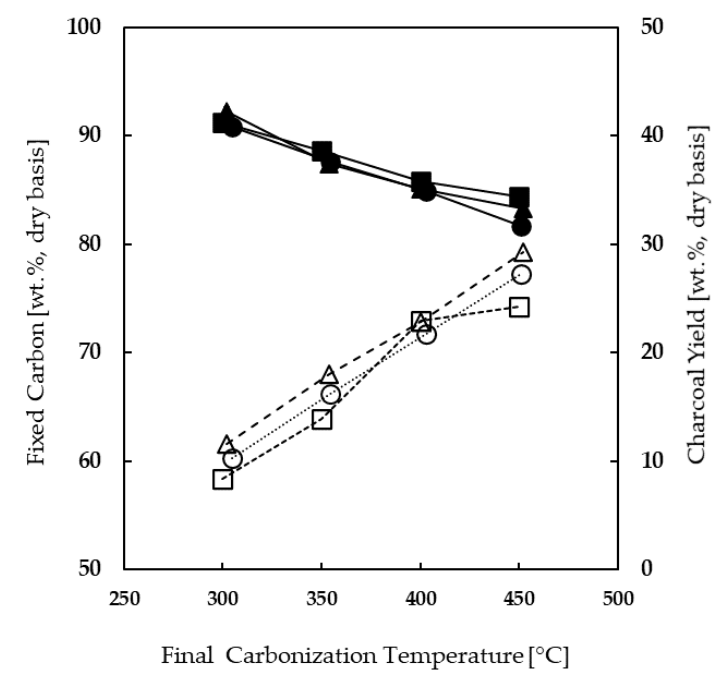

Figure 3. Charcoal's fixed carbon content (open symbols, $\mathrm{kg}$ fixed carbon $/ \mathrm{kg}$ dry charcoal) and yield (solid symbols, $\mathrm{kg}$ dry charcoal/ $\mathrm{kg}$ dry wood) as a function of final carbonization temperature, during tests with holm oak (squares), cork oak (circles), and eucalyptus globulus (triangles), at $1{ }^{\circ} \mathrm{C} / \mathrm{min}$.

\subsection{Effect of Wood Type}

\subsubsection{Total Mass, Elemental, Ash, and Enthalpy Balances and Particle Shrinkage}

Figure 4a provides the quantities of total mass, elements $(\mathrm{CHO})$, volume, and enthalpy that remain in the charcoal particle after carbonization at $400^{\circ} \mathrm{C}$ and $1{ }^{\circ} \mathrm{C} / \mathrm{min}$, which are expressed as ratios relative to the respective quantities initially present in the dry wood particles; actually, the mass and enthalpy ratios are the same as the usual operational parameters of mass and energy efficiencies, respectively. The most visible result is that the values obtained for the balances depend highly upon the quantity under focus and notably less on the type of wood. The values for charcoal's yield (dry basis) varied from $0.33 \mathrm{~kg} / \mathrm{kg}$ for acacia mimosa and $0.37 \mathrm{~kg} / \mathrm{kg}$ for olive tree (holm oak, i.e., the reference wood, yielded $0.36 \mathrm{~kg} / \mathrm{kg}$ ). This range of charcoal's yield is small considering the number of wood types tested and the $\pm 2 \%$ uncertainty associated to this parameter. It also shows that the differences observed for e.g., lignin content or density of wood (Figure 2) do not give rise to major differences in the charcoal's yield. If this analysis is done in terms of specific elements, then it turns out that only a small fraction of the masses of hydrogen and oxygen initially present in the wood particles remain in the charcoal particles. Depending on the wood type, we observed a fraction ranging from 0.15 to 0.20 for $\mathrm{H}$ and from 0.13 to 0.16 for $\mathrm{O}$. In the case of elemental carbon, this amount rises to more than half: between 0.52 and 0.6 of the mass of carbon in the dry wood remains in the charcoal. This underlines how the volatile products released during the carbonization of dry wood convey high amounts of oxygen and hydrogen, e.g., in the form of carbon oxides and water, as also noted with other operating conditions [7]. Regarding particle shrinkage, the volume of the charcoal particles is within 0.42 to 0.55 (average of 0.51 ) of the volume of the dry wood particles. This corresponds to average shrinkages of $\approx 21 \%$ in diameter and $\approx 15 \%$ in length. Particle volume shrinkage is the parameter with major variations among the ten wood types tested, with a slight trend for the three densest woods (holm oak, cork oak, and olive tree) to afford larger volume contractions. In general, the charcoal particles kept the cylindrical shape of the original wood particles, with the exception being the eucalyptus charcoal with a barrel-like geometry. Almost all charcoal particles exhibited cracks-even if no cracks were observed in the original wood particles-while fragmentation was negligible. Concerning the enthalpy balances-i.e., based on the LHV of wood and charcoal-the results show that charcoal retains a fraction between 0.50 and 0.59 of the energy presents in the original wood particle (Figure 4a). This places the carbonization process at a high level in terms of energy efficiency, with values comparable to those typical of biomass gasification and 
combustion (to electricity) processes [29,30], even if the energy released as volatile matter is discarded.
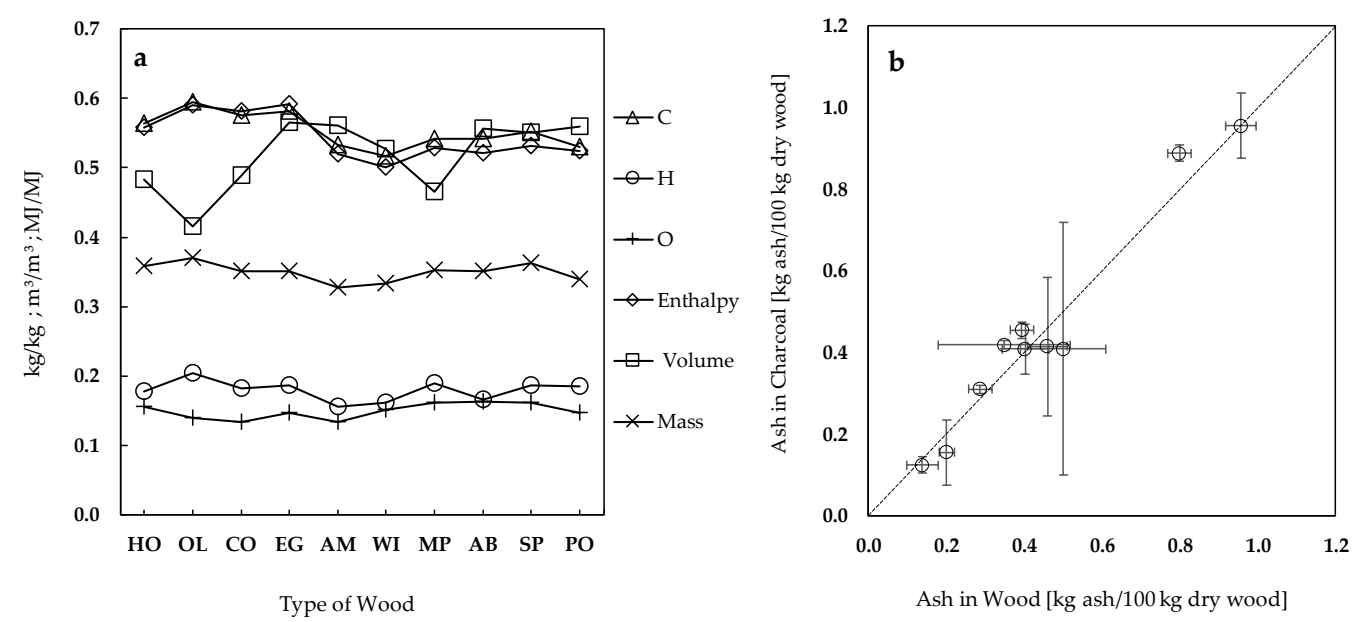

Figure 4. Quantities of (a) main elements $(\mathrm{C}, \mathrm{H}, \mathrm{O})$, enthalpy, volume, total mass, and (b) ash remaining in the charcoal particles in relation to the respective quantities initially present in the dry wood particles, during experiments conducted at $1{ }^{\circ} \mathrm{C} / \mathrm{min}$ and final temperature of $400{ }^{\circ} \mathrm{C}$. Wood abbreviations according to legend in Figure 2.

Concerning the ash balance-i.e., mass of ash in the charcoal particles per unit mass of ash in the dry wood particles-the values obtained are within 0.8-1.2. Values above 1 are unrealistic because the mass of ash in the charcoal particles should not be greater than the mass of ash initially present in the wood particles. However, the low ash contents of wood and charcoal can raise the uncertainties associated to the ash balances, and this should be considered when interpreting the results. To highlight uncertainties contributions, Figure $4 \mathrm{~b}$ details the ash balance separately. In general, the uncertainty values are within $\pm 0.1 \mathrm{~kg}$ of ash per $100 \mathrm{~kg}$ of dry wood with the exceptions being the balances for poplar and the two acacias. There are a few cases with values above 1 even if uncertainties are taken into account. In these cases, it is possible that the wood samples subjected to analysis may have slightly different compositions than the wood samples placed in the reactor for carbonization, which leads to higher uncertainties. However, what can be stated from an overall analysis of Figure $4 \mathrm{~b}$ is that considering the uncertainties, it is not possible to rule out that the totality of the wood ash remains in the corresponding charcoal particles.

\subsubsection{Charcoal Properties}

Following the analysis about the properties of the wood feedstocks in Figure 2 (Section 3.2), Figure 5 shows the properties of the respective charcoals obtained at $400{ }^{\circ} \mathrm{C}$ and $1{ }^{\circ} \mathrm{C} / \mathrm{min}$, again given as ratios relative to those of holm oak charcoal-the base data are also given in Table 2. 
Table 2. Properties of the charcoals obtained at $1{ }^{\circ} \mathrm{C} / \mathrm{min}$ and final temperature of $400{ }^{\circ} \mathrm{C}$.

\begin{tabular}{|c|c|c|c|c|c|c|c|}
\hline \multicolumn{8}{|c|}{ Average \pm One Std. Deviation (Dry Basis) } \\
\hline Fuels & $\begin{array}{c}\text { Fixed } \\
\text { Carbon }\end{array}$ & Ash & $\mathrm{O} / \mathrm{C}$ & $\mathrm{H} / \mathrm{C}$ & $\begin{array}{c}\text { Elemental } \\
\text { Carbon }\end{array}$ & $\begin{array}{c}\text { Apparent } \\
\text { Density }\end{array}$ & LHV \\
\hline & $(w t \%)$ & $(w t \%)$ & $(\mathrm{kg} / \mathrm{kg})$ & $(\mathrm{kg} / \mathrm{kg})$ & $(w t \%)$ & $\left(\mathrm{kg} / \mathrm{m}^{3}\right)$ & (MJ/kg) \\
\hline Holm oak & $73.0 \pm 0.5$ & $2.7 \pm 0.23$ & $0.26 \pm 0.01$ & $0.04 \pm 0.003$ & $74.6 \pm 0.3$ & $660 \pm 20$ & $26.7 \pm 1.5$ \\
\hline Olive tree & $76.4 \pm 1.1$ & $1.1 \pm 0.15$ & $0.21 \pm 0.02$ & $0.05 \pm 0.001$ & $78.6 \pm 0.3$ & $690 \pm 7$ & $29.0 \pm 1.9$ \\
\hline Cork oak & $71.8 \pm 3.0$ & $2.5 \pm 0.04$ & $0.23 \pm 0.05$ & $0.04 \pm 0.001$ & $76.4 \pm 0.3$ & $509 \pm 20$ & $27.7 \pm 0.8$ \\
\hline Eucalyptus globulus & $72.8 \pm 2.5$ & $0.4 \pm 0.23$ & $0.25 \pm 0.01$ & $0.04 \pm 0.002$ & $76.7 \pm 0.2$ & $387 \pm 7$ & $27.6 \pm 1.3$ \\
\hline Acacia mimosa & $74.5 \pm 1.2$ & $1.3 \pm 0.52$ & $0.24 \pm 0.01$ & $0.04 \pm 0.001$ & $76.8 \pm 0.2$ & $334 \pm 6$ & $27.7 \pm 1.3$ \\
\hline Gray willow & $71.7 \pm 0.8$ & $1.4 \pm 0.07$ & $0.26 \pm 0.01$ & $0.04 \pm 0.004$ & $75.5 \pm 0.3$ & $349 \pm 11$ & $27.0 \pm 1.3$ \\
\hline Maritime pine & $72.7 \pm 0.2$ & $0.4 \pm 0.06$ & $0.26 \pm 0.01$ & $0.05 \pm 0.001$ & $76.0 \pm 0.4$ & $394 \pm 5$ & $27.5 \pm 1.0$ \\
\hline Australian blackwood & $70.1 \pm 2.4$ & $1.2 \pm 0.89$ & $0.27 \pm 0.01$ & $0.04 \pm 0.002$ & $75.2 \pm 0.1$ & $299 \pm 10$ & $26.8 \pm 1.5$ \\
\hline Stone pine & $72.2 \pm 0.8$ & $0.9 \pm 0.02$ & $0.24 \pm 0.01$ & $0.05 \pm 0.001$ & $76.8 \pm 0.4$ & $313 \pm 9$ & $27.9 \pm 0.8$ \\
\hline Poplar & $71.9 \pm 0.5$ & $1.2 \pm 0.02$ & $0.25 \pm 0.01$ & $0.05 \pm 0.002$ & $76.2 \pm 0.4$ & $252 \pm 10$ & $27.7 \pm 1.6$ \\
\hline
\end{tabular}

(1) following the method based on Archimedes' principle.

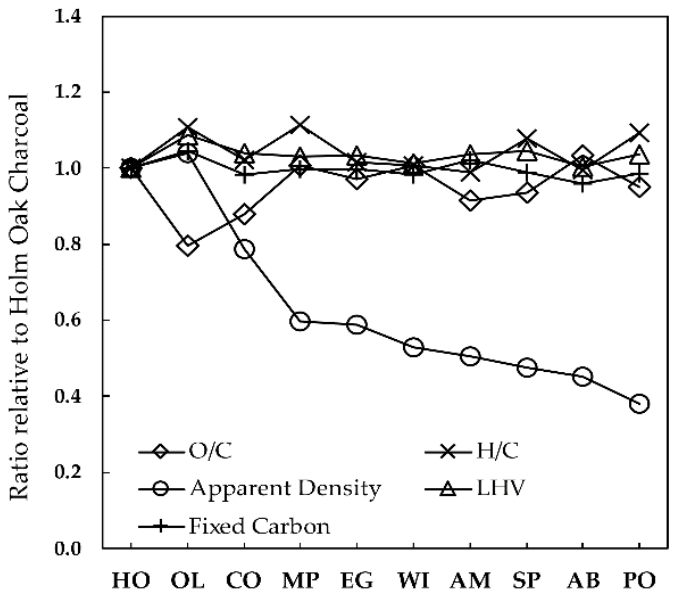

Figure 5. Ratios of charcoal properties obtained from distinct wood types in relation to those of holm oak charcoal. Wood abbreviations according to legend in Figure 2.

As discussed in Section 3.4.1, the carbonization process leads to a massive release of elemental oxygen and hydrogen from the converting solid fuel, while the release of elemental carbon is much lower. The result is that the solid fraction arising from the process becomes highly enriched in both elemental carbon and fixed carbon, as compared to feedstock. For holm-oak-i.e., the reference fuel in this work-the results show an increase of elemental carbon content from $47.3 \mathrm{wt} \%$, in dry wood, to $74.6 \mathrm{wt} \%$, in dry charcoal. The corresponding increase for the fixed carbon content is from $16.3 \mathrm{wt} \%$ to $73.0 \mathrm{wt} \%$. If this analysis is extended to the whole set of woods, it can be seen that the range of values for elemental carbon and fixed carbon enrichments is similar. For the elemental carbon content of charcoal, the values are between 0.99 and 1.05 of the values for holm-oak charcoal, or between $74.6 \mathrm{wt} \%$ and $78.6 \mathrm{wt} \%$ if expressed on a dry charcoal basis. This range is of the same order of magnitude of the measurement uncertainties associated with the elemental analysis $( \pm 3 \%)$, thus suggesting that the carbon content of charcoal has a small dependence on the type of wood for the samples studied. The same applies to the charcoal's fixed carbon contents, with values within 0.95 to 1.05 of that obtained for holm-oak charcoal, or within 70.1-76.4 wt \% on a dry charcoal basis. The slightly higher elemental carbon contents as compared to fixed carbon contents (e.g., $74.6 \mathrm{wt} \%$ C vs. $73.0 \mathrm{wt} \% \mathrm{FC}$ for the case of holm-oak charcoal) are due to the small amount of volatile matter still present in the charcoal owing to the mild temperatures used in this work. These high carbon contents of charcoal make the respective $\mathrm{O} / \mathrm{C}$ and $\mathrm{H} / \mathrm{C}$ elemental 
mass ratios drop sharply as compared to those of wood: from $0.83-1.01 \mathrm{kgO} / \mathrm{kgC}$ and $0.14-0.15 \mathrm{kgH} / \mathrm{kgC}$ in the original woods, to $0.21-0.27 \mathrm{kgO} / \mathrm{kgC}$ and $0.04-0.05 \mathrm{kgH} / \mathrm{kgC}$ in the charcoals (see Tables 1 and 2). Again, a similar range of $\mathrm{O} / \mathrm{C}$ and $\mathrm{H} / \mathrm{C}$ ratios were obtained among the 10 charcoal types analyzed. In its turn, the low $\mathrm{O} / \mathrm{C}$ mass ratios enable the charcoal to show significantly higher lower heating values (LHV) as compared to wood: from 16.4-19.0 MJ/kg, for dry wood, to 26.7-29.0 MJ/kg, for dry charcoal, which represents an increment of about $50 \%$. This also corresponds to about $80-90 \%$ of the LHV of graphite $(32.8 \mathrm{MJ} / \mathrm{kg}$ [31]), thus showing that the carbonization process generates high-quality charcoals without the need of harsh conditions. The results highlight that the ash content of charcoals is 2.7 to 3 times higher than those of woods, which is in line with the fact that the major part of ash in the feedstock remains in the charcoal. In contrast to the small differences found for the proximate and elemental compositions, and LHV of charcoals, the respective apparent density varies considerably, as also observed for the case of wood in Figure 2. As a rule, there is a significant reduction of solid density when wood is converted into charcoal. Under the conditions of this study-carbonization of dry wood particles at $1^{\circ} \mathrm{C} / \mathrm{min}$ to $400^{\circ} \mathrm{C}$ final temperature-the apparent density of charcoal is on average $68 \pm 9 \%$ of that of the original wood particles, which is comparable with results from other studies $[32,33]$. Holm oak and olive tree are the wood types producing the densest charcoals ( $>650 \mathrm{~kg} / \mathrm{m}^{3}$ in Table 2$)$, while poplar produces the least dense charcoal $\left(\approx 250 \mathrm{~kg} / \mathrm{m}^{3}\right.$ or a ratio of 0.36 if expressed in relation to holm oak charcoal as in Figure 5). Concerning other dominant tree species in Portugal (and Southern Europe), cork oak produces the third densest charcoal with just above $500 \mathrm{~kg} / \mathrm{m}^{3}$, while maritime pine, stone pine, and eucalyptus produce charcoals with less than $400 \mathrm{~kg} / \mathrm{m}^{3}$.

To get insight into the extent to which the apparent density of charcoals depends on the cellular macrostructure of the original wood particles, pore size measurements were performed for the charcoals obtained from holm oak, cork oak, eucalyptus globulus, maritime pine, and poplar. The results show small variations in the skeletal pore volumebetween 0.0024 and $0.0034 \mathrm{~cm}^{3} / \mathrm{g}$-which corresponds to charcoal skeletal porosities of less than $1 \%$. This reveals a non-porous skeletal structure with minimum spaces between graphite-like layers of flat aromatic carbon clusters. Nevertheless, the high porosities obtained following the Archimedes' principle-up to $\approx 90 \%$ for poplar charcoal, which is equivalent to $\approx 250 \mathrm{~kg} / \mathrm{m}^{3}$ of apparent density-suggest a major presence of macroporosity that is not associated with the skeletal. These results agree with other studies showing that charcoal macro-porosity accounts for more than $95 \%$ of total porosity $[34,35]$. Further SEM analysis of charcoal's surface confirmed the presence of complex cellular structures typical of wood (see Figure 6 for the cases of poplar and eucalyptus charcoals). This indicates that the cellular structure of wood remains intact after carbonization and defines charcoal's apparent density. 


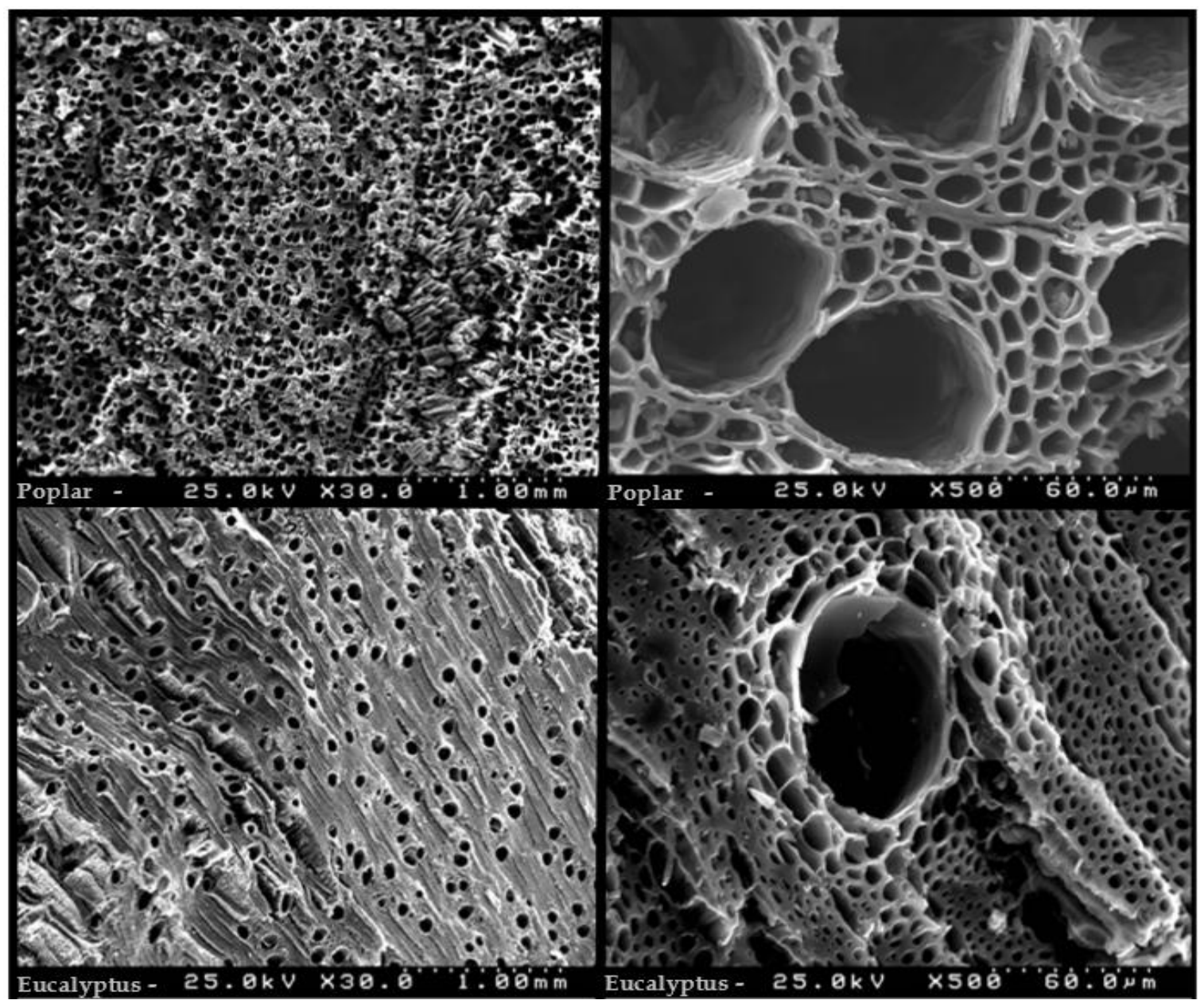

Figure 6. SEM micrographs of charcoals from poplar (top) and Eucalyptus globulus (bottom), as obtained at $400{ }^{\circ} \mathrm{C}$ and $1{ }^{\circ} \mathrm{C} / \mathrm{min}$, with a magnification of $\times 30$ (left) and $\times 500$ (right). The samples are shown in a cross-section cut perpendicular to the direction of the wood fibers.

\subsection{Effect of the Heating Rate and Wood Moisture}

Two additional variables that vary considerably during carbonization operations are the heating rate of the wood bed and wood moisture, due to the widely different carbonization systems under use $[16,36]$ and because wood stacking is often carried out under atmospheric conditions. To get an initial impression of the effect of these variables, some additional carbonization tests were performed with holm oak wood, in which the heating rate was changed between $0.1,1$, and $5{ }^{\circ} \mathrm{C} / \mathrm{min}$ and wood moisture between 0 and $30 \mathrm{wt} \%$ (while keeping the heating rate at $1{ }^{\circ} \mathrm{C} / \mathrm{min}$ ). To mimic the wetting process of the wood in real conditions, the original wood particles were moistened by immersion in distilled water for a couple of days to reach the desired moisture content.

Visually, the effect of increasing the heating rate is that the charcoal particles exhibit more cracks on the surface. This may be due to larger temperature gradients inside the converting wood particles that promote a faster release of volatiles and subsequent breakdown of wood structures during intra-particle transport. Comparing with the results at $1{ }^{\circ} \mathrm{C} / \mathrm{min}$, carbonization at $5{ }^{\circ} \mathrm{C} / \mathrm{min}$ leads to a $15 \%$ decrease in charcoal yield, while the effect on charcoal properties is smaller (fixed carbon content decreases only $\approx 5 \%$, and the ratio between the apparent densities of charcoal and wood particles decreases $\approx 10 \%$ ). The corresponding variations due to decreasing the heating rate from 1 to $0.1^{\circ} \mathrm{C} / \mathrm{min}$ are even smaller and insignificant if the uncertainties of measurements are considered. In any case, the trend is that decreasing the heating rate to $0.1^{\circ} \mathrm{C} / \mathrm{min}$ improves both charcoal's yield 
and properties (e.g., carbon content, LHV). If wet wood particles (i.e., $30 \mathrm{wt} \%$ moisture) are used, the result is that the cracking phenomenon of the charcoal particles is exacerbated. The explanation for this might be due to the formation and transport of larger amounts of steam inside the particles that can lead to the rupture of particle structures. Regarding its effect on charcoal's yield and properties, carbonization of the wet wood particles results in slightly lower values of mass yield, fixed carbon content, and apparent density (decreases of less than $10 \%$ ) as compared to the carbonization of dry wood particles.

\subsection{Evaluation of Charcoal Properties in Relation to the European Standard and Barbeque Grill Market}

The EN1860-2-2005:E standard (Appliances, solid fuels, and firelighters for barbecueingPart 2: Barbecue charcoal and barbecue charcoal briquettes-Requirements and test methods) establishes a set of requirements for barbeque charcoal, including a minimum fixed carbon content of dry charcoal of $75 \mathrm{wt} \%$, maximum ash content of dry charcoal of $8 \mathrm{wt} \%$, maximum moisture content of as-received charcoal of $8 \mathrm{wt} \%$, charcoal particle size distribution up to $150 \mathrm{~mm}$, and minimum charcoal bulk density of $130 \mathrm{~kg} / \mathrm{m}^{3}$. Among these parameters, charcoal moisture, particle size distribution, and bulk density were not tested in this work. Moisture was not tested because the charcoal particles recovered from the reactor were already dry. For the other two unmeasured parameters, the reason is that this work deals with the properties of single charcoals particles, while the standard addresses the properties of a mass of many particles.

In terms of fixed carbon content, most charcoals obtained at $400{ }^{\circ} \mathrm{C}$ and $1{ }^{\circ} \mathrm{C} / \mathrm{min}$ approach the minimum $75 \mathrm{wt} \%$ threshold, with the exception being the olive charcoal with $76.3 \mathrm{wt} \%$. The average value among the different charcoal types obtained in this work nearly coincides with the fixed carbon content of holm oak charcoal (73.0 wt \%). However, the results in Figure 3 show that the fixed carbon content of charcoal can be easily increased by adjusting the final carbonization temperature to above $400{ }^{\circ} \mathrm{C}$. Therefore, it seems possible to prepare charcoals meeting the threshold of $75 \mathrm{wt} \%$ of fixed carbon content from all types of wood tested in this work. From the point of view of consumers, high fixed carbon contents are associated with high-quality charcoals for barbecueing. For instance, a study on marketing aspects of barbeque charcoal [36] showed that volatile matter contents above $30 \mathrm{wt} \%$ are associated with embers that easily lead to flame and high-smoke emissions that might contain some quantity of harmful compounds. This can be particularly relevant during the refueling process of the barbeque with fresh charcoal particles. In this work, all charcoal types showed volatile matter contents under $30 \mathrm{wt} \%$ (maximum was $28.7 \mathrm{wt} \%$ for Australian blackwood charcoal). The ash content of charcoal is also a relevant parameter for consumers. High ash charcoals demand frequent cleaning and maintenance of barbequing systems, as well as it creates ticker ash layers over the embers that can be dragged to the food. However, all charcoal types obtained here exhibited ash contents well below the $8 \mathrm{wt} \%$ threshold given in the standard (actually below $3 \mathrm{wt} \%$, Table 2).

Another two charcoal properties not referred in the standard but that might be important for consumers are the LHV and apparent density. High LHV charcoals are associated with high-temperature embers, quick food preparation, and less charcoal feed during barbequing. The LHV of holm oak charcoal, $\approx 27 \mathrm{MJ} / \mathrm{kg}$ (dry basis), can be taken as a reference value, since this charcoal is perceived by consumers (and producers) as of high quality; again, minor differences in LHV were found between the 10 charcoal types obtained here (see Table 2). Regarding density, Júnior [37] referred that consumers often associate highdensity charcoals with quality barbeques, having the notion that it means lower friability, fewer fines, and the possibility of preparing more food. In addition, there are other aspects linking density to charcoal quality perceptions. Charcoal is sometimes sold in bags with a given volume, which means that consumers have the notion that it is more economical to buy a bag with denser charcoal as it accommodates more mass of fuel. In addition, there is the perception that a bed of denser charcoal burns more slowly, which can be essential for some end-users. Indeed, the existence of two sub-markets for barbeque charcoal- 
i.e., professional users and residential users - can raise the interest for the production of low-density charcoals from alternative wood types. These low-density charcoals may be good enough for residential barbeques requiring small amounts of charcoal and where embers are needed during short periods (typically less than $30 \mathrm{~min}$ ). In this sense, charcoals with smaller particle sizes may be also more suitable for these users, since burnout times are proportional to particle size [38]. It has been shown that the carbonization of $50 \mathrm{~mm}$ diameter wood pieces (at $400{ }^{\circ} \mathrm{C}$ and $1{ }^{\circ} \mathrm{C} / \mathrm{min}$ ) originates charcoal particles of suitable diameters for the market (see Section 3.4.1). On the contrary, professional barbecues such as restaurants and barbeque grill street food demand long operational times (several hours), which means that high-density charcoals such as those from holm oak and cork oak can be especially suited for them. Finally, from the point of view of producers and logistics operators, density is also relevant as it influences both costs and fines generation during screening, bagging, road transport, and storage.

\section{Conclusions}

A bench-scale fixed bed facility was used to investigate the carbonization behavior of 10 wood types common in Portugal and Southern Europe, under operating conditions that are relevant for charcoal production systems (heating rate within $0.1-5^{\circ} \mathrm{C} / \mathrm{min}$, final temperature within $300-450{ }^{\circ} \mathrm{C}$, large wood particle sizes, wood moisture up to $30 \mathrm{wt} \%$ ). Apart from a detailed physical-chemical analysis of the original woods, the resulting charcoals were collected to evaluate the balances of the process and to obtain its most relevant properties.

Wood apparent density varies considerably more than other wood properties studied in this work (proximate and elemental analysis, lignin content, LHV), and its structural arrangement is preserved after withstanding temperatures typical of carbonization kilns. Then, the structure of charcoal is linked to that of the original wood, and its apparent density is positively correlated to the apparent density of the original wood. As a result, the apparent density of charcoal also varies widely compared to other charcoal properties studied. If the focus is on the top-five wood types in the Portuguese forestry sector (cork oak, holm oak, eucalyptus globulus, maritime pine, and stone pine), then it turns out that holm-oak wood produces significantly denser charcoals, which agrees with the fact that it is considered a reference product in the market. However, it is possible to produce charcoals complying with EN1860-2-2005:E standard for barbeque charcoal from all wood types tested in this work. The attainment of suitable fixed carbon contents-minimum $75 \mathrm{wt} \%$, dry basis, according to the standard-is a critical issue that can be overcome by proper adjustment of the operating conditions. Raising the carbonization temperature is a straightforward way of improving charcoal quality, albeit at the expense of lower yields. On the other hand, reducing the heating rate from 1.0 to $0.1^{\circ} \mathrm{C} / \mathrm{min}$ improves charcoal quality and yield, although the gains are marginal and may not compensate for the much higher carbonization times.

Carbonization enables the conversion of various types of wood into charcoal-a valuable product for which both the production infrastructure and markets already exist. For the specific case of barbecue charcoal, the utilization of alternative wood types to the two types currently used on a large scale in Portugal—holm oak and cork oak-is only a market issue, including the aspects related to wood availability and charcoal price/quality relation. In this context, the existence of two main sub-markets for barbeque charcoal-professional and household users, the latter with lower quality requisites-can raise the interest for the carbonization of undervalued wood varieties or even wood feedstocks with smaller particle sizes, both of which can lead to charcoals of lower quality but yet suitable for household applications. This can contribute to diversifying the fuel supply chain associated with current charcoal activities in Portugal, with marketing and information actions aimed at both producers and consumers being needed to explore these opportunities within the barbeque market. Moreover, future work can also unveil specialized markets in e.g., 
industrial and agricultural sectors, which can raise the interest for the carbonization of specific wood types.

Author Contributions: Conceptualization, D.N.; methodology, F.C., D.N., A.M.; resources, A.M., L.T.; investigation, F.C., L.R., F.S., D.N.; data curation, F.C., L.R.; formal analysis, F.C.; writing-original draft preparation, F.C., D.N.; writing—review and editing, F.C., L.R., F.S., L.T., A.M., J.F.d.S., D.N.; supervision, D.N., A.M.; project administration, D.N., A.M.; funding acquisition, D.N. All authors have read and agreed to the published version of the manuscript.

Funding: This research was funded by national funds through FCT—Fundação para a Ciência e a Tecnologia, I.P./Ministry of Science, Technology and Higher Education, within the scope of the project CHARCLEAN (PCIF/GVB/0179/2017), CESAM (UIDP/50017/2020+UIDB/50017/2020) and Ph.D. scholarship (SFRH/BD/129901/2017).

Institutional Review Board Statement: Not applicable.

Informed Consent Statement: Not applicable.

Data Availability Statement: Data available on request due to project policies.

Conflicts of Interest: The authors declare no conflict of interest.

\section{References}

1. European Commission (EC). A Sustainable Bioeconomy for Europe: Strengthening the Connection between Economy, Society and the Environment; European Commission: Brussels, Belgium, 2018; Legal Communication. (2018) 673/2 and SWD (2018)431/2. [CrossRef]

2. Governo de Portugal Resolução do Conselho de Ministros no $163 / 2017-P l a n o$ Nacional para a Promoção das Biorrefinarias. Diário da República, Número 163/2017, Páginas: 5839-5847, 2017. Available online: https:/ /dre.pt/home/-/dre/114133883/details / maximized (accessed on 31 October 2017).

3. Zhao, C.; Jiang, E.; Chen, A. Volatile production from pyrolysis of cellulose, hemicellulose and lignin. J. Energy Inst. 2017, 90, 902-913. [CrossRef]

4. Hagemann, N.; Spokas, K.; Schmidt, H.P.; Kägi, R.; Böhler, M.A.; Bucheli, T.D. Activated carbon, biochar and charcoal: Linkages and synergies across pyrogenic carbon's ABCs. Water 2018, 10, 182. [CrossRef]

5. Ronsse, F.; van Hecke, S.; Dickinson, D.; Prins, W. Production and characterization of slow pyrolysis biochar: Influence of feedstock type and pyrolysis conditions. GCB Bioenergy 2013, 5, 104-115. [CrossRef]

6. Demirbaş, A. Relationships between Carbonization Temperature and Pyrolysis Products from Biomass. Energy Explor. Exploit. 2004, 22, 411-419. [CrossRef]

7. Neves, D.; Thunman, H.; Matos, A.; Tarelho, L.; Gómez-Barea, A. Characterization and prediction of biomass pyrolysis products. Prog. Energy Combust. Sci. 2011, 37, 611-630. [CrossRef]

8. Dufourny, A.; Van De Steene, L.; Humbert, G.; Guibal, D.; Martin, L.; Blin, J. Influence of pyrolysis conditions and the nature of the wood on the quality of charcoal as a reducing agent. J. Anal. Appl. Pyrolysis 2019, 137, 1-13. [CrossRef]

9. Qambrani, N.A.; Rahman, M.M.; Won, S.; Shim, S.; Ra, C. Biochar properties and eco-friendly applications for climate change mitigation, waste management, and wastewater treatment: A review. Renew. Sustain. Energy Rev. 2017, 79, 255-273. [CrossRef]

10. Jelonek, Z.; Drobniak, A.; Mastalerz, M.; Jelonek, I. Environmental implications of the quality of charcoal briquettes and lump charcoal used for grilling. Sci. Total Environ. 2020, 747, 141267. [CrossRef]

11. Antal, M.J.; Grønli, M. The art, science, and technology of charcoal production. Ind. Eng. Chem. Res. 2003, 42, 1619-1640. [CrossRef]

12. Knapp, H.; Nelle, O.; Kirleis, W. Charcoal usage in medieval and modern times in the Harz Mountains Area, Central Germany: Wood selection and fast overexploitation of the woodlands. Quat. Int. 2015, 366, 51-69. [CrossRef]

13. Nelle, O. Charcoal burning remains and forest stand structure-examples from the Black Forest (SW-Germany) and the Bavarian Forest (SE-Germany). In Proceedings of the Second International Meeting of Anthracology, 1063, Paris, France, 5 September 2000; Thiébault, S., Ed.; BAR International Series: Oxford, UK, 2002; pp. 201-208.

14. Carrari, E.; Ampoorter, E.; Bottalico, F.; Chirici, G.; Coppi, A.; Travaglini, D.; Verheyen, K.; Selvi, F. The old charcoal kiln sites in Central Italian forest landscapes. Quat. Int. 2017, 458, 214-223. [CrossRef]

15. Food and Agriculture Organization (FAO). Forestry Production and Trade-Wood Charcoal. Available online: http://www.fao. org/faostat/en/\#data/FO (accessed on 31 January 2021).

16. Silva, F.T.M.; Silva, J.J.F.; Silva, D.; Tarelho, L.A.C.; Matos, M.A.A.; Neves, D. Charcoal production infrastructure in Portalegre district (Portugal): First assessment from satellite imagery and field observations. 3rd Bioenergy Int. Conf. 2019, 52, 1. [CrossRef]

17. Ferreira, S.; Monteiro, E.; Brito, P.; Vilarinho, C. Biomass resources in Portugal: Current status and prospects. Renew. Sustain. Energy Rev. 2017, 78, 1221-1235. [CrossRef] 
18. Gírio, F.; Duarte, L.C.; Silva, L.; Lukasik, R.; Fernando, A.L.; Nunes, C.P.; Cunha, J.L.; Dias, M.S.; Almeida, T.; Nicolau, A.; et al. Biomass in Portugal: Current Uses and New Policies for Bioenergy Development. Be-Sustain. Mag. 2019, 10, 17-22.

19. Molina-Terrén, D.M.; Xanthopoulos, G.; Diakakis, M.; Ribeiro, L.; Caballero, D.; Delogu, G.M.; Viegas, D.X.; Silva, C.A.; Cardil, A. Analysis of forest fire fatalities in Southern Europe: Spain, Portugal, Greece and Sardinia (Italy). Int. J. Wildl. Fire 2019, $28,85-98$. [CrossRef]

20. Monteiro, E.; Mantha, V.; Rouboa, A. Portuguese pellets market: Analysis of the production and utilization constrains. Energy Policy 2012, 42, 129-135. [CrossRef]

21. Nunes, L.J.R.; Matias, J.C.O.; Catalão, J.P.S. Wood pellets as a sustainable energy alternative in Portugal. Renew. Energy 2016, 85, 1011-1016. [CrossRef]

22. European Committee for Standardization (CEN). Appliances, Solid Fuels and Firelighters for Barbecueing-Part 2: Barbecue Charcoal and Barbecue Charcoal Briquettes-Requirements and Test Methods; EN1860-2-2005:E; European Committee: Brussels, Belgium, 2003.

23. Charvet, F.; Silva, F.; Pio, D.; Tarelho, L.; Matos, A.; Silva, J.; Neves, D. Charcoal production from alternative agroforestry woody residues typical of southern Europe. In Proceedings of the 28th European Biomass Conference and Exhibition Proceedings, Marseille, France, 6-9 July 2020; pp. 368-376. [CrossRef]

24. Channiwala, S.A.; Parikh, P.P. A unified correlation for estimating HHV of solid, liquid and gaseous fuels. Fuel 2002, 81, 1051-1063. [CrossRef]

25. Neves, D.; Matos, A.; Tarelho, L.; Thunman, H.; Larsson, A.; Seemann, M. Volatile gases from biomass pyrolysis under conditions relevant for fluidized bed gasifiers. J. Anal. Appl. Pyrolysis 2017, 127, 57-67. [CrossRef]

26. Hughes, S.W. Archimedes revisited: A faster, better, cheaper method of accurately measuring the volume of small objects. Phys. Educ. 2005, 40, 468-474. [CrossRef]

27. Mara dos Santos Barbosa, J.; Ré-Poppi, N.; Santiago-Silva, M. Polycyclic aromatic hydrocarbons from wood pyrolyis in charcoal production furnaces. Environ. Res. 2006, 101, 304-311. [CrossRef]

28. Bustos-Vanegas, J.D.; Martins, M.A.; de Cassia Oliveira Carneiro, A.; Freitas, A.G.; Barbosa, R.C. Thermal inertia effects of the structural elements in heat losses during the charcoal production in brick kilns. Fuel 2018, 226, 508-515. [CrossRef]

29. Pio, D.T.; Tarelho, L.A.C.; Pinto, P.C.R. Gasification-based biorefinery integration in the pulp and paper industry: A critical review. Renew. Sustain. Energy Rev. 2020, 133, 110210. [CrossRef]

30. Koppejan, J. The Handbook of Biomass Combustion and Co-Firing; Routledge: London, UK, 2012; ISBN 9781849773041.

31. Çengel, Y.A.; Boles, M.A. Thermodynamics: An Engineering Approach; McGraw-Hill, Inc.: New York, NY, USA, 2006; ISBN 9780070606593.

32. Shi, Y.; Chrusciel, L.; Zoulalian, A. Production of charcoal from different wood species. Récents Progrès en Génie des Procédés 2007, $96,9$.

33. Chrzazvez, J.; Théry-Parisot, I.; Fiorucci, G.; Terral, J.F.; Thibaut, B. Impact of post-depositional processes on charcoal fragmentation and archaeobotanical implications: Experimental approach combining charcoal analysis and biomechanics. J. Archaeol. Sci. 2014, 44, 30-42. [CrossRef]

34. Brewer, C.E.; Chuang, V.J.; Masiello, C.A.; Gonnermann, H.; Gao, X.; Dugan, B.; Driver, L.E.; Panzacchi, P.; Zygourakis, K.; Davies, C.A. New approaches to measuring biochar density and porosity. Biomass Bioenergy 2014, 66, 176-185. [CrossRef]

35. Gray, M.; Johnson, M.G.; Dragila, M.I.; Kleber, M. Water uptake in biochars: The roles of porosity and hydrophobicity. Biomass Bioenergy 2014, 61, 196-205. [CrossRef]

36. Rodrigues, T.; Braghini Junior, A. Charcoal: A discussion on carbonization kilns. J. Anal. Appl. Pyrolysis 2019, 143. [CrossRef]

37. Júnior, A.F.D. Carvão Vegetal para Cocção de Alimentos: Aspectos Mercadológicos e de Qualidade Para o Consumo. Ph.D. Thesis, (Doctorate in Forest Resources). Universidade de São Paulo, Escola Superior de Agricultura "Luiz de Queiroz", Piracicaba, Brazil, 2018.

38. Riaza, J.; Gibbins, J.; Chalmers, H. Ignition and combustion of single particles of coal and biomass. Fuel 2017, 202, 650-655. [CrossRef] 